\title{
Isolation Studies of Leptospira in Andhra Pradesh
}

\author{
Dr. D. Rani Prameela ${ }^{1}$, Dr. D. Sreenivasulu ${ }^{2}$, Dr. P. Vijayachari ${ }^{3}$, Dr. Ch. Srilatha ${ }^{4}$, Dr. S. Vijaya Lakshmi ${ }^{5}$ \\ ${ }^{1,2,5}$ Department of Veterinary Microbiology, C.V.SC., Sri Venkateswara Veterinary University, Tirupati, Andhra Pradesh, India \\ ${ }^{3}$ Director, ICMR, Port Blair, Center for Diagnosis and typing of leptospira, Andaman and Nicobar Islands \\ ${ }^{4}$ Department of Veterinary Pathology, C.V.SC., Sri Venkateswara Veterinary University, Tirupati, Andhra Pradesh, India
}

\begin{abstract}
Isolation attempts were carried out between November 2006 and May 2010. Samples collected from clinically suspected cases of cattle (26), sheep (42), dogs (13), pigs (15), humans (53), stagnated water (10) in Rice fields and from rats (299) were inoculated in to EMJH liquid medium with tween- 80, antibiotics and 5- fluorouracil. A total of 17 isolates were recovered, from sheep (5), pigs (4), humans (2), rice field water (1) and from rats (5). The isolates were purified and maintained in EMJH liquid medium and as well as semi solid medium. The Physio-chemical characterization of isolates at $13^{\circ} \mathrm{C}$, growth in the presence of 8 - Azaguanine, Lipase activity and animal inoculation studies revealed the pathogenicity of the isolates. The isolates were identified using Dark field microscopy, Fontana's staining, characteristic Dingers phenomenon and by histopathological studies.
\end{abstract}

Keywords: Leptospira, EMJH medium, Dark field microscopy, Fontana's staining, Physico chemical characterisation and Histopathology

\section{Introduction}

Leptospirosis is a world wide zoonosis and is considered as a re-emerging disease. In spite of economic losses to the animal production by the bacterium, its zoonotic character makes it an important public health problem [1]. Leptopsirosis can be diagnosed by several laboratory methods of which the serological methods are the most widely used [9], [7] and [1] but the isolation of Leptospira allows the definite diagnosis of individual infections.

It also helps to study molecular epidemiology of the disease and to develop suitable vaccine to control the disease.. In Andhra Pradesh, so far no data related to isolation of leptospires from naturally infected animals and from reservoir hosts like rodents is available.

The information available on Leptospirosis is limited to serology. Hence, attempt was made for isolation of leptospires from infected animals, humans and rats to find out epidemiological link between animals, humans and rats. The pathogenicity of the isolates were confirmed by using physico-chemical characterization, biological and histopathological methods.

\section{Materials and Methods}

\subsection{Collection of Samples}

Samples were collected during the period from February 2006 to May 2010. A total of 159 samples from clinically suspected cases of Cattle (26), Sheep (42), Dogs (13), Pigs (15), Humans (53), stagnated water in Rice fields of outbreak area (10). A $10 \%$ homogenous suspension of kidneys and livers collected from 299 Rats trapped from different geographical areas.

\subsection{Preparation of EMJH Medium}

EMJH liquid medium with Tween 80, Antibiotics and 5fluorouracil was used as a selective medium according to [4] with slight modifications.

\subsection{Preparation of Leptospira Base}

$1.15 \mathrm{~g}$ of EMJH base (Difco) dissolved in $500 \mathrm{ml}$ of triple distilled water (Sterile) was used for preparation of media.

\subsection{Preparation of Nutrient supplement consisting of}

\begin{tabular}{|c|c|}
\hline BSA fraction $V$ & $5.0 \mathrm{~g}$ \\
\hline $\mathrm{CaCl}_{2}$ (stock solution) & $0.5 \mathrm{ml}$ \\
\hline $\mathrm{ZnSo}_{4}$ (Stock solution) & $0.5 \mathrm{ml}$ \\
\hline $\mathrm{MnSo}_{4}$ (Stock solution) & $50.0 \mu 1$ \\
\hline $\mathrm{FeSO}_{4}$ (Stock solution) & $5.0 \mathrm{ml}$ \\
\hline $\mathrm{MgCl}_{2}$ (Stock solution) & $0.5 \mathrm{ml}$ \\
\hline Vit-B $_{12}($ Stock solution $)$ & $0.5 \mathrm{ml}$ \\
\hline Tween 80 (Stock solution) & $0.5 \mathrm{ml}$ \\
\hline $\mathrm{CuSo}_{4}$ (stock solution) & $0.2 \mathrm{ml}$ \\
\hline Nalidixic acid (stock solution) & $1.0 \mathrm{ml}$ \\
\hline Lactalbumin hydrolysate & $0.5 \mathrm{~g}$ \\
\hline Sodium pyruvate & $0.02 \mathrm{~g}$ \\
\hline L-Cystine & $10 \mathrm{mg}$ \\
\hline Distilled water & $22.5 \mathrm{ml}$ \\
\hline
\end{tabular}

The base and supplement were sterilized by 0.45 and 0.22 $\mu \mathrm{m}$ pore size filter membrane and mixed at the ratio of 9:1. The medium is dispensed in aliquots in $5 \mathrm{ml}, 10 \mathrm{ml}$ screw capped sterile test tubes. Each of two test tubes, one kept at room temperature and another at $37^{\circ} \mathrm{C}$ for $48 \mathrm{hrs}$ and remaining tubes at $4^{\mathrm{O}} \mathrm{C}$ to check for contaminants. After 48 hrs, if there is no contamination, all the tubes were kept at $25^{\mathrm{O}} \mathrm{C}-30{ }^{\circ} \mathrm{C}$ in BOD incubator for future use.

\subsection{Isolation of Leptospira}

All the clinical samples collected were processed and inoculated into EMJH liquid media and incubated at $29^{\circ} \mathrm{C} \pm$ $1^{\circ} \mathrm{C}$ in B.O.D. incubator and screened for presence of Leptopira at weekly intervals under dark-field microscope.

\subsection{Purification of Leptospiral isolates}

2.6.1 Filtration: Leptospiral isolates obtained from different sources were purified by filtration through Cellulose 


\section{International Journal of Science and Research (IJSR) \\ ISSN (Online): 2319-7064 \\ Index Copernicus Value (2013): 6.14 | Impact Factor (2014): 5.611}

membrane filters with $0.22 \mu \mathrm{m}$. (M/S Sartorius, India) and cultured freshly into EMJH media.

2.6.2 Animal inoculation: Pathogenic studies were carried out in Guinea Pigs weighing 150 to 250 gms. (I/P). 12 hours of post inoculation $0.5 \mathrm{ml}$. of heart blood was inoculated into EMJH media for re-isolation.

\subsection{Identification of Leptospira Isolates}

2.7.1 Dark field microscopy: Isolates obtained were initially observed under Dark-field microscope for their characteristic motility.

2.7.2 Fontana's staining: done with ADMAS staining kit.

2.7.3 Sub surface growth in semi-solid EMJH medium: for specific growth for cultural character.

2.7.4 Histopathological examination: Liver and Kidney tissues from inoculated Guinea Pigs were collected in 10\% formalin for Histopathological studies and stained with Haematoxylin \& Eosin for examination.

\subsubsection{Physico-Chemical characterization:}

2.7.5.1 Growth at $13^{\circ} \mathrm{C}$ : Along with known pathogenic and saprophytic strains of leptospira in duplicates incubating once at $13^{\circ} \mathrm{C}$ and another set at $30^{\circ} \mathrm{C}$. Growth was checked twice in a week up to 21 days.

\subsubsection{Growth in the presence of 8-Azaguanine:}

Incubated the tubes both test and control at $30^{\circ} \mathrm{C}$ with and without 8-Azaguanine. Growth was checked twice in a week up to 21 days.

2.7.6 Reaction on egg yolk agar media: To study the lipase activity of Leptopiral isolates.

\section{Results}

\subsection{Isolation of Leptospira}

A total of 17 Leptospiral isolates, 5 from Sheep, 4 from Pigs, 2 from Humans, 1 from Rice field water and 5 from Rodents were recovered from 458 clinical samples collected from different species

with percentage positivity of $3.7 \%$ up on culturing. (Table: 1).

Table 1: Details of clinical samples collected and Leptospiral isolates recovered Purification of leptospira

\begin{tabular}{|c|c|c|c|c|}
\hline S.No & $\begin{array}{c}\text { Source of } \\
\text { isolation }\end{array}$ & $\begin{array}{c}\text { No. of samples } \\
\text { subjected for } \\
\text { isolation }\end{array}$ & $\begin{array}{c}\text { No. of samples } \\
\text { found positive }\end{array}$ & $\begin{array}{c}\text { Percent } \\
\text { positivity }\end{array}$ \\
\hline 1 & Rats & 299 & 5 & 1.67 \\
\hline 2 & Sheep & 42 & 5 & 11.91 \\
\hline 3 & Pigs & 15 & 4 & 26.6 \\
\hline 4 & Humans & 53 & 2 & 3.77 \\
\hline 5 & Rice field & 10 & 1 & 10 \\
\hline 6 & Cattle & 26 & - & - \\
\hline 7 & Dogs & 13 & - & - \\
\hline & TOTAL & 458 & 17 & 3.71 \\
\hline
\end{tabular}

The leptospira isolates recovered during the period i.e., five from rats, five from sheep, four from pigs, two from humans and one from rice field water, were further subjected to membrane filtration using $0.22 \mathrm{~m} \mu$ membrane filters for purification. Later, sub culturing was done on EMJH medium regularly and finally maintained on EMJH semisolid medium for further studies.

\subsection{Animal inoculation}

All the 17 isolates recovered on cultural isolation were inoculated into guinea pigs individually for further purification. The blood samples of respective guinea pigs were further inoculated into fresh EMJH liquid medium and re-isolated the organisms in pure form.

\subsection{Identification of leptospira}

The leptospiral isolates obtained during the isolation were maintained in EMJH liquid medium as well as semi solid medium. In the semi solid medium the characteristic sub surface growth, dinger's phenomenon was observed (Fig. 1).

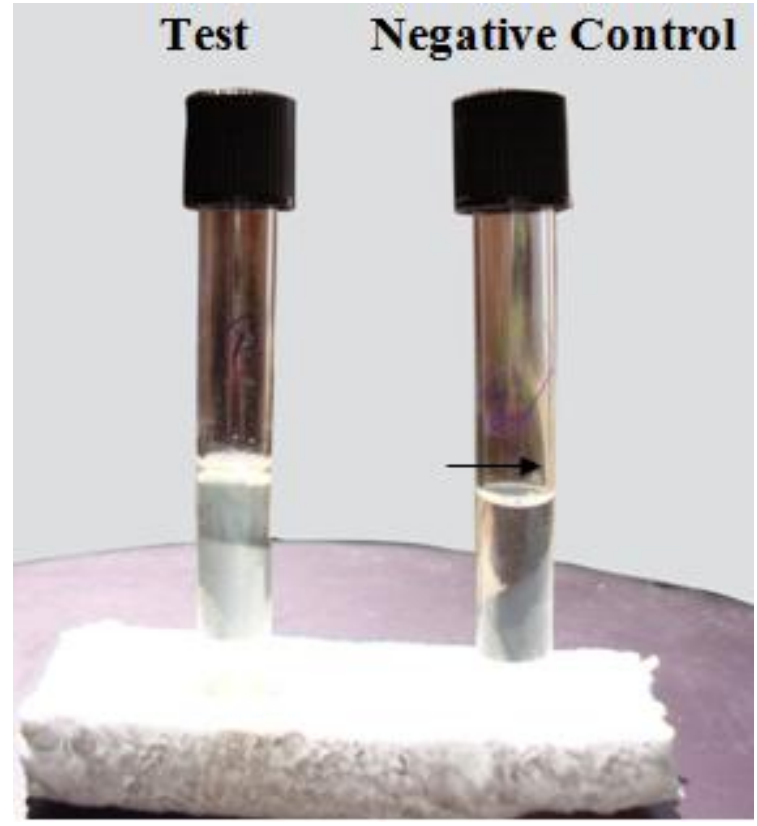

Figure 1: Growth pattern of Leptospira isolate S3 in semisolid agar medium - Dinger's Phenomenon

Test : Leptospira isolate (S3)

Negative Control: Negative Control

The isolates obtained from different species were identified initially by using dark field microscopy and by staining methods.

\subsection{Dark field microscopy}

The leptospiral isolates obtained were observed under dark field microscopy. The organisms were actively motile. The characteristic motility of flexion, extension and rotational movements were observed under dark field microscope suggestive of leptospires. 


\section{International Journal of Science and Research (IJSR) \\ ISSN (Online): 2319-7064}

Index Copernicus Value (2013): 6.14 | Impact Factor (2014): 5.611

\subsection{Fontana's Staining}

The 17 isolates of leptospira recovered in pure form were stained using ADMAS staining kit, and observed the characteristic morphology of spiral shape with hooked ends. All the organisms showed characteristic morphological features of the leptospira and seen as brownish black with yellow color back ground (Fig.2),

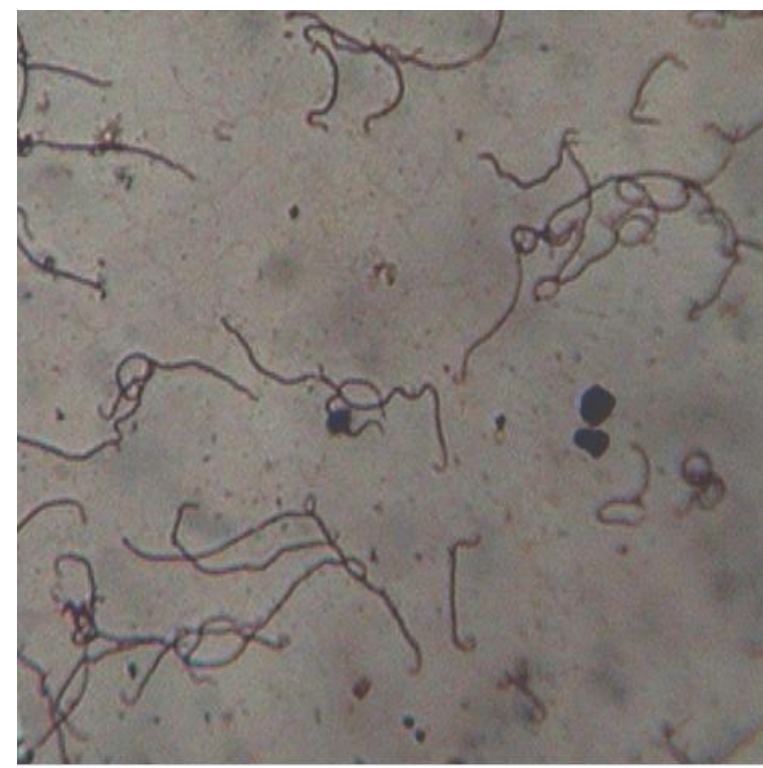

Figure 2: Fontana's staining of leptospira isolate

\subsection{Histopathology}

The histopathological studies of liver and kidney collected from infected guinea pigs revealed focal areas of congestion, severe degeneration with vacculation in hepatic cell, dilatation of sinusoidal spaces, sinusoidal haemorrhages, infiltration of neutrophils, eosinophils, proliferation of bile ducts and perivascular mononuclear cell infiltration. In majority of the cases ninucleated hepatic cells were prominent (Fig.4.a,b,c,d and e).

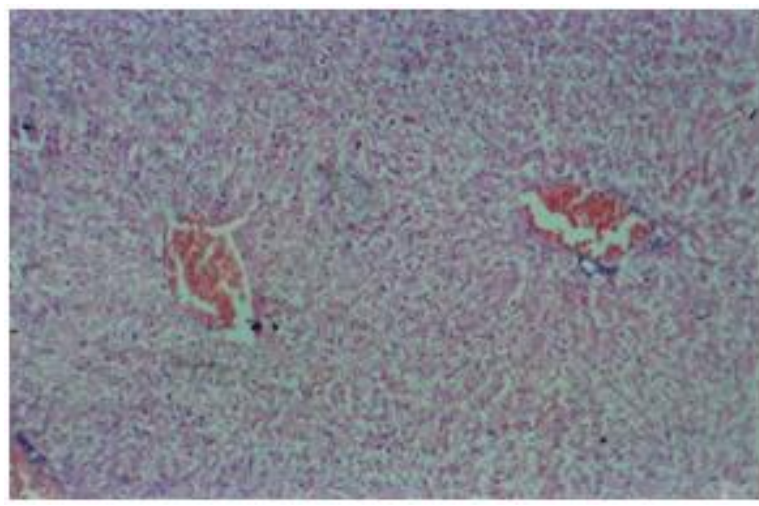

Figure 4: Histopathology - liver of Guinea pigs infected with leptospira

4.a. Severe congestion $H \&$ E X 70

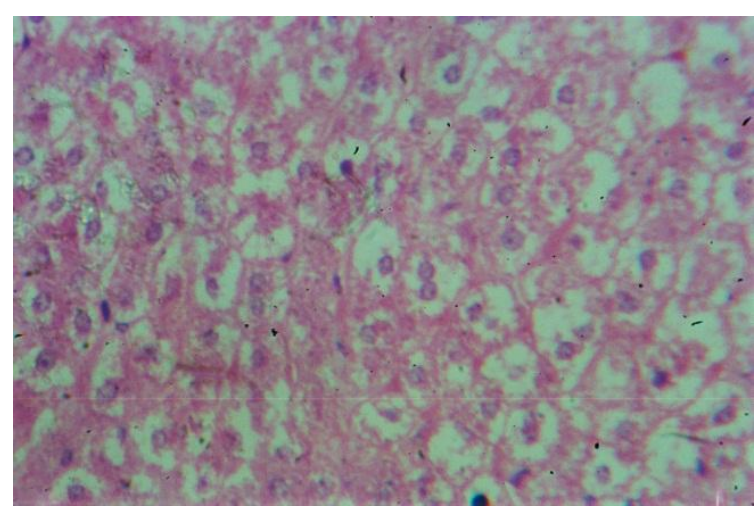

Figure 4 (b): Severe degenerative changes in hepatic cells with vacuolation $\mathrm{H} \&$ E X 280

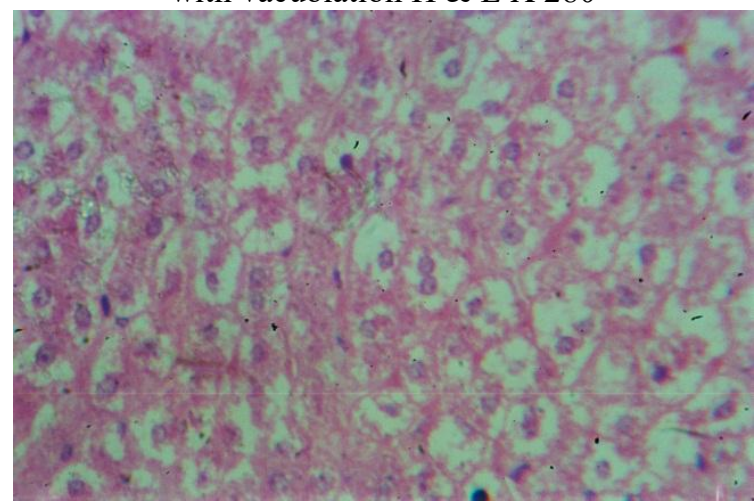

Figure 4 (c): Dilatation of sinusoidal space with haemorrhages and infiltration of neutrophils and eosinophils H \& E X 280

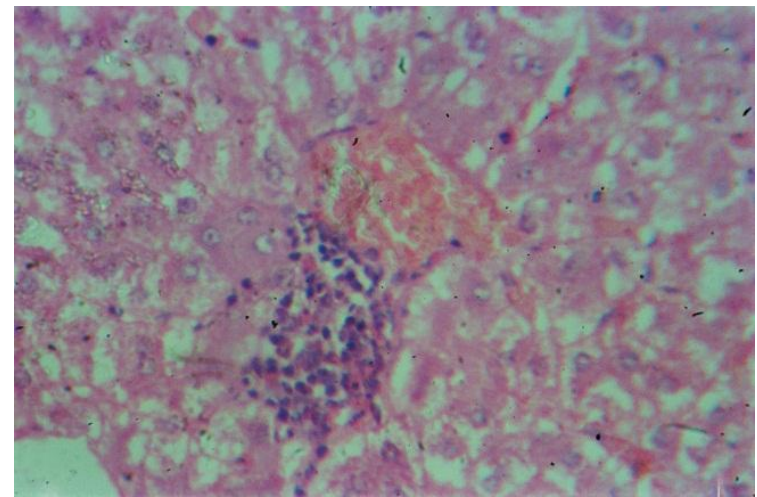

Figure 4 (d): Perivascular, mononuclear aggregation $\mathrm{H} \& \mathrm{E}$

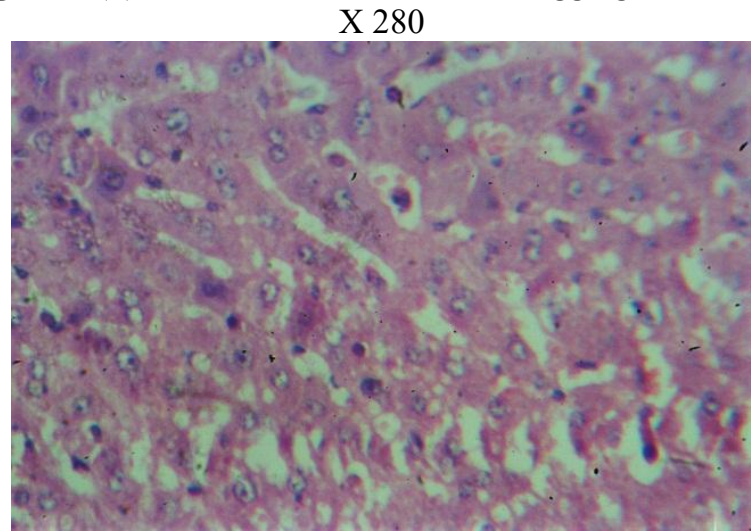

Figure 4 (e): Several binucleated hepatic cells H \& E x 280

In kidneys, focal areas of congestion, glomerular congestion, intertubular haemorrhages, periglomerular infiltration of neutrophils and monocytes, inter tubules infiltration of mononuclear cells i.e. interstitial nephritis, vacculation and inter tubular fibrosis were recorded (Fig. 5.a,b,c and d). 


\section{International Journal of Science and Research (IJSR) \\ ISSN (Online): 2319-7064}

Index Copernicus Value (2013): 6.14 | Impact Factor (2014): 5.611

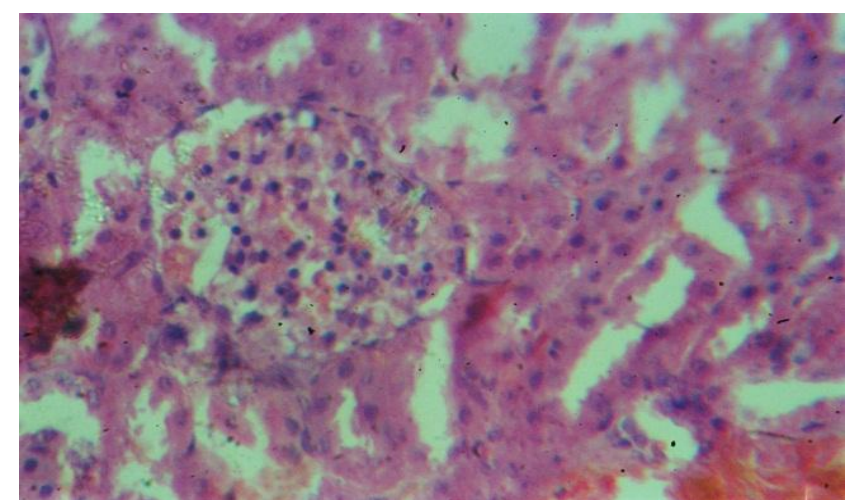

Figure 5: Histopathology - kidney of guinea pig infected with leptospira

5 (a): Glomerular infiltration H \& E X 280

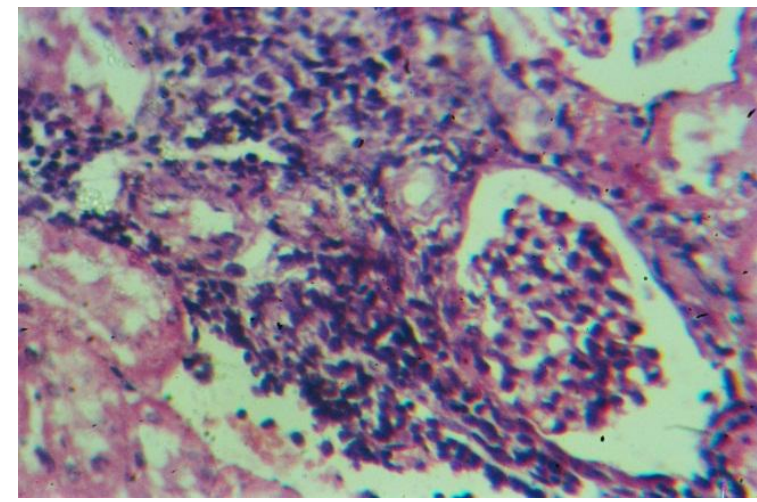

Figure 5 (b): Periglomerular and intertubular infiltration $\mathrm{H}$ \& E X 280

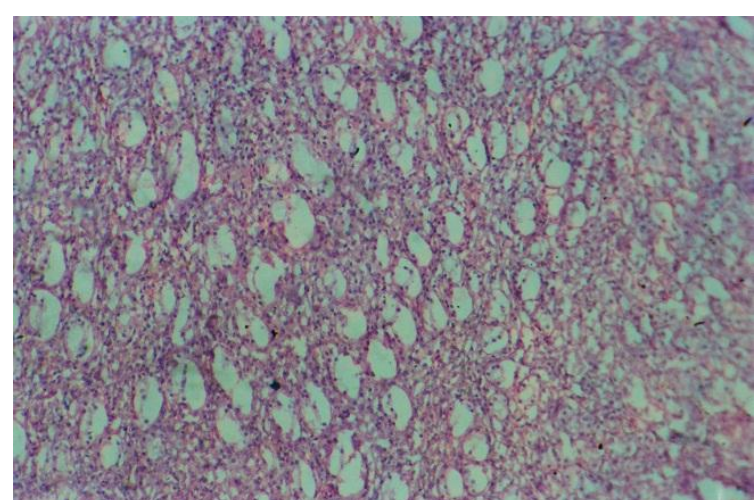

Figure 5 (c): Cystic dilatation of tubules \& E X 70

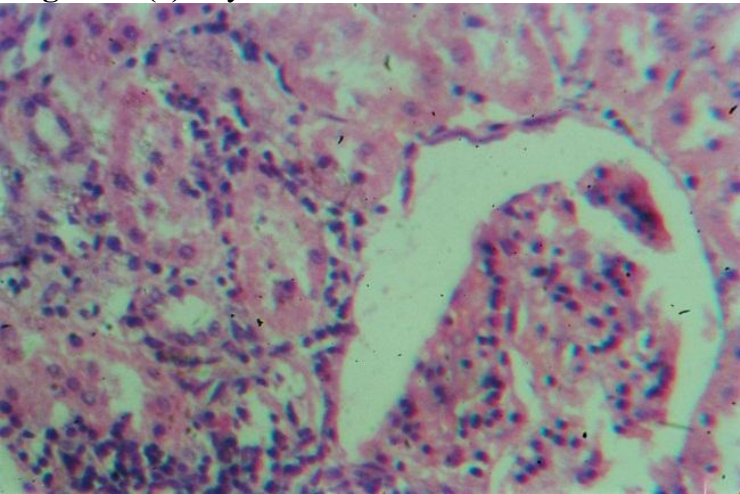

Figure 5 (d): Intratubular infiltration of mononuclear cells $\mathrm{H} \& \mathrm{E}$ X 280

\subsection{Physico chemical characterization}

The leptospira isolates isolated form different species were subjected for physicochemical characterization, growth at $13^{\mathrm{O}} \mathrm{C}, 8$-Azaguanine test and reaction on Egg-Yolk agar to differentiate pathogenic and non pathogenic leptospires.

\subsection{Growth at $13^{\circ} \mathrm{C}$}

All the 17 leptospira isolates fail to grow at $13^{\circ} \mathrm{C}$ indicating the pathogenicity. Results of the study shown in (Table 2).

Table 2: Growth characterization of leptospiral isolates

\begin{tabular}{|c|c|c|c|c|c|c|c|c|c|}
\hline \multirow{3}{*}{ S.No } & \multirow{3}{*}{$\begin{array}{c}\text { Source of } \\
\text { leptospiral } \\
\text { isolates }\end{array}$} & \multirow{3}{*}{$\begin{array}{l}\text { No. of } \\
\text { samples } \\
\text { tested }\end{array}$} & \multirow{3}{*}{$\begin{array}{c}\text { No. of } \\
\text { leptospiral } \\
\text { Isolates } \\
\text { obtained }\end{array}$} & \multicolumn{2}{|c|}{ Growth at } & \multicolumn{4}{|c|}{ Controls } \\
\hline & & & & \multirow{2}{*}{$13^{\circ} \mathrm{C}$} & \multirow{2}{*}{$30^{\circ} \mathrm{C}$} & \multicolumn{2}{|c|}{ Reference pathogenic } & \multicolumn{2}{|c|}{ Reference Non -pathogenic } \\
\hline & & & & & & $13^{\circ} \mathrm{C}$ & $30^{\circ} \mathrm{C}$ & $13^{\circ} \mathrm{C}$ & $30^{\circ} \mathrm{C}$ \\
\hline 1 & Rats & 299 & 5 & - & + & - & + & + & - \\
\hline 2 & Sheep & 42 & 5 & - & + & - & + & + & - \\
\hline 3 & Pigs & 15 & 4 & - & + & - & + & + & - \\
\hline 4 & Humans & 53 & 2 & - & + & - & + & + & - \\
\hline 5 & Rice field & 10 & 1 & - & + & - & + & + & - \\
\hline 6 & Cattle & 26 & - & - & - & - & + & + & - \\
\hline
\end{tabular}

\subsection{8-Azaguanine test}

The 17 leptospiral isolates were not grown in the presence of 8 -azaguanine. The control pathogenic strains L.interrogans also fail to grown in the presence of 8-azaguanine. However, growth of non pathogenic strain L.patoc was noticed (Table 3). 


\section{International Journal of Science and Research (IJSR) \\ ISSN (Online): 2319-7064 \\ Index Copernicus Value (2013): 6.14 | Impact Factor (2014): 5.611}

Table 3: Growth characterization of Leptospiral isolates in the presence of 8-Azaguanine

\begin{tabular}{|c|c|c|c|c|c|c|c|c|c|}
\hline \multirow{3}{*}{$\begin{array}{l}\text { S. } \\
\text { No }\end{array}$} & \multirow{3}{*}{$\begin{array}{c}\text { Source of } \\
\text { leptospiral isolates }\end{array}$} & \multirow{3}{*}{$\begin{array}{c}\text { No.of samples } \\
\text { Tested }\end{array}$} & \multirow{3}{*}{$\begin{array}{l}\text { No.of leptospiral } \\
\text { Isolates obtained }\end{array}$} & \multicolumn{2}{|c|}{ Growth } & \multicolumn{4}{|c|}{ Control } \\
\hline & & & & \multirow{2}{*}{$\begin{array}{c}\text { With } \\
\text { 8-azaguanine }\end{array}$} & \multirow{2}{*}{$\begin{array}{c}\text { Without } \\
\text { 8-azaguanine }\end{array}$} & \multicolumn{2}{|c|}{ Ref pathogen } & \multicolumn{2}{|c|}{ Ref. non pathogen } \\
\hline & & & & & & With & Without & With & without \\
\hline 1 & Rats & 299 & 5 & $-\mathrm{ve}$ & $+\mathrm{ve}$ & -ve & + ve & $+\mathrm{ve}$ & $+\mathrm{ve}$ \\
\hline 2 & Sheep & 42 & 5 & -ve & + ve & -ve & + ve & + ve & + ve \\
\hline 3 & Pigs & 15 & 4 & -ve & $+\mathrm{ve}$ & -ve & $+\mathrm{ve}$ & $+\mathrm{ve}$ & $+\mathrm{ve}$ \\
\hline 4 & Humans & 53 & 2 & -ve & + ve & -ve & + ve & $+\mathrm{ve}$ & + ve \\
\hline 5 & Rice fields & 10 & 1 & -ve & + ve & -ve & + ve & + ve & + ve \\
\hline 6 & Cattle & 26 & - & - & - & - & - & - & - \\
\hline & Total & 445 & 17 & & & & & & \\
\hline
\end{tabular}

\section{Reaction on Egg - Yolk agar}

All the 17 isolates showed lipase activity on egg yolk agar plates indicating pathogenicity (Fig.3).

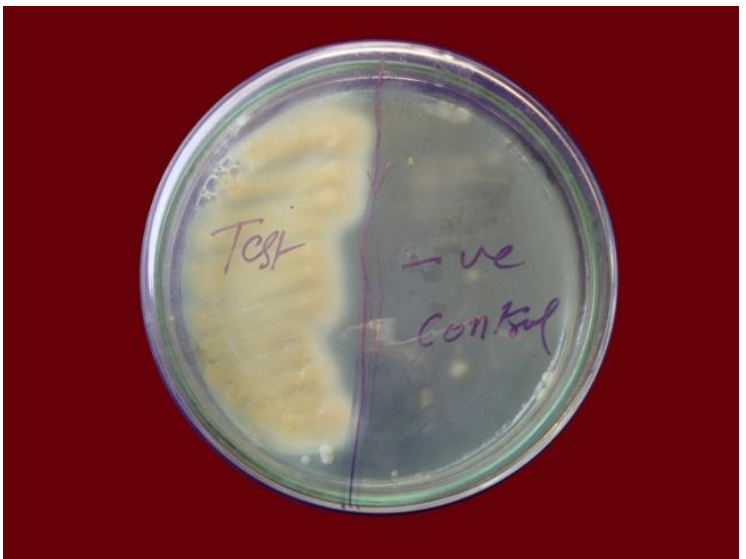

Figure 3: Lipase activity of leptospira on egg yolk agar

Test: Leptospira isolate (S3)

Negative Control: Negative Control (Non pathogenic)

\section{Discussion}

EMJH liquid medium with tween 80, antibiotics and 5flurouracil was used as selective media for isolation and maintenance of leptospira. Similarly, EMJH liquid media with tween 80 , antibodies was also used by the earlier workers [19], [18], [17] and [10] for isolation and maintenance of leptospires in their studies. [16] reported the harmful effect of antibiotics on leptospiral growth after 48 hrs incubation. However, such effect of antibiotics on growth of leptospira was not noticed during our investigation.

A total of 299 kidney samples from rats of different places were cultured in EMJH liquid medium. Leptospira was isolated from five of the 299 samples cultured from rats and five from the 42 samples cultured from sheep, four from the 15 samples cultured from pigs. Similarly, two leptospiral isolates were obtained from 53 blood samples cultured from humans. Out of ten water samples cultured, leptospira was isolated from one sample.

During the study, leptospiral organisms were observed in EMJH media between 12-14 weeks of inoculation. [11] and [3] also observed leptospira between 12 to 14 weeks. Keeping in views of slow growth of leptospira, [13] suggested observing for the period of 4 to six months for isolation of leptospria.
Leptospiral isolations could not be made from the samples collected during the period of study from cattle (26) and dogs (13). There is a need to improve the methodology suitably. Isolation of leptospira from clinical samples is an art, requires skill and experience. Successful isolation depends on the time of collection, interval between collection and processing, number of leptospira present in the samples, the interference of contaminating organisms and tissue autolysis. [8], [12] and [5]. The organisms growing in the EMJH liquid media were initially tested under darkfield microscopy and noticed the flexion, extension and rotational motility characteristic of leptospira.

In the present study pathogenic studies were conducted in guinea pigs and leptospiral organisms were re-isolated. Histopathological examination of liver and kidney collected from infected guinea pigs revealed congestion, degeneration, vacuolation, sinusoidal haemorrhages, perivascular mononuclear infiltration in hepatic cells, buinucleated and majority cases hepatic cells were binucleated. This type of changes in the liver was reported by [14]. Histopathological examination of kidney samples revealed the focal areas of congestion, glomerulor congestion, periglomerular infiltration of neutrophils and monocytes, interstitial nephritis, intertubular fibrosis were observed during the study. Similar type of lesions in kidneys were also recorded by $[14]$.

A total of 17 isolates received from sheep (5), pigs (4), rats (5), humans (2) and rice field (1) were maintained in the laboratory for further study. The isolates when stained with ADMAS staining kit showed the spiral shape with hooked ends the characteristic morphological features of the leptospira and were seen as brownish black organisms with yellow back ground Fig. 12. [2] also used ADMAS staining kit and reported the presence of leptospira.

Characterization of leptospiral isolates is an important tool for identification of leptospiral strains. Leptospiral isolates that were confirmed conventionally were subjected to physico-chemical characterization an was assessed by studying the leptospial growth at $13^{\circ} \mathrm{C}$, in the presence of 8 azaguanine and reaction on egg-yolk agar to differentiate pathogenic from non pathogenic leptospires. During the study all the 17 leptospiral isolates fail to grow at $13^{\circ} \mathrm{C}$ and in the presence of 8-azaguanine. All the isolates showed lipase activity on egg-yolk agar indicating the pathogenic nature of leptospira [4], [15], [10] and [6] also differentiated pathogenic leptospires from non pathogenic by 


\section{International Journal of Science and Research (IJSR) \\ ISSN (Online): 2319-7064 \\ Index Copernicus Value (2013): 6.14 | Impact Factor (2014): 5.611}

growing at $13^{\circ} \mathrm{C}$, studying the effect of 8 -azaguanine and lipase activity.

\section{Acknowledgement}

Authors are thankful to Sri Venkateswara Veterinary University, Tirupati, Andhra Pradesh, India for providing financial support.

\section{References}

[1] S. Faine, B. Alder, C. Bolin and P. Perolat, "Leptospira and leptospirosis", Medical Science, Melbourne. 1999.

[2] N. L. Gangadhar and M. A. Rajasekhar, "Modified silver impregnation staining for leptospires", Indian Veterinary Journal, 75, pp. 349-351, 1998.

[3] F. Gibson, da Silva Zacaries, Silva Arruda Vasconcells, Eleine Kuroki Anzai, Nilson Girald, Jullio Casar de Frietas, Rudy Hartiskeri, "Isolation of leptospria serovar canicola and copenhageni from cattle urine in the state of Parane, Brazil", Brazil Journal of Microbiology, 39, pp. 4, 2008.

[4] R. C. Johnson and V. G. Harris, "Differentiation of pathogenic and saprophytic Leptospires, growth at low temperatures", Journal of Bacteriology, 94, pp. 27-31, 1967.

[5] Office International-des-Epizooties, "Leptospirosis In: Manual of standards for diagnostic tests and vaccine", OIE, Paris, 2008.

[6] J. U. ShuklaTuteja and H. V. Batra, "16S rRNA PCR for differentiation of pathogenic and nonpathogenic leptospiral isolates", Indian journal of Medical Microbiology, 21, (1) pp. 25-30, 2003.

[7] A. B. Thiermann and L. A. Garrett, "Enzyme-linked immunosorbent assay for the detection of antibodies to Leptospira interrogans serovar hardjo and pomona in cattle", American Journal of Veterinary Research, 44, pp. 884-887, 1983.

[8] A B.Thiermann, Leptospirosis: "Current developments and trends", Journal of American Veterinary Medicine Association, 184, pp. 722-725, 1984.

[9] L. H.Turner, "Leptospirosis II. Serology", Transactions of the Royal Society of Tropical Medicine and Hygiene, 6, pp. 880-899, 1968.

[10] P. Vijayachari, S. C. Sehgal, M. G. Goris, W. J. Terpstra and Hartskeerl, "Leptospira interrogans serovar valbuzzi: A cause of severe pulmonary haemorrhages in Andaman Islands", Journal of Medical Microbiology, 52, pp. 913-918, 2003.

[11] P. Vijayachari, "Leptospira, In: Leptospirosis loboratory manual", Regional Medical Research Centre, Indian Council of Medical Research, Port Blair, India, 2007.

[12]M. D. Venkatesha, SohanLal, and G.Krishnappa,"Leptospirosis in Man and Animals in Karnataka”, Intas Polivet, 7, pp. 324-329, 2006.

[13] World Health Organisation, "Human Leptospirosis: Guidance for diagnosis, Surveillance and control", Geneva, World Health Organisation, 2003.

[14] S. R. Zaki, and R. A. Sehgal, "Leptospirosis", In A.M. Nelson and C.R. Horsburgh (ed.), Pathology of emerging infections 2. American Society for Microbiology, Washington, D.C. pp. 73-92, 1998.
[15] R. Noubade, G. V. S. Krishnamurthy Murag, , M. D. Venkatesha and G. Krishnappa, Indian Journal of Medical Microbiology 20, (1), pp.33-36, 2002.

[16]A. Schonberg, "Studies on the effect of antibiotic substances on Leptospires and their cultivation from material with a high bacterial count", Zbl. Bakt. Hygiene, 249, pp. 400-406, 1981.

[17] N.L.Gangadhar rao, M. Rajasekhar, L.D.Smythe, M.A.Norris, M.L. Symonds and M.F.Dohnt Rev, "Reservoir hosts of Leptospira Inadai In India",Scie. Tech. off. Int. Eppiz., 19, (03), pp. 793-799, 2000.

[18] N. Gregoire, R. Higgins and Y. Robinson, "Isolation of leptospires from nephritic kidneys of beef cattle at slaughter", American Journal Of Veterinary Research, 48, pp. 370-371, 1987.

[19] W.A. Ellis, J.J.O’ Brien and J. Cassels, “ Role of cattle in the maintainance of Leptospira Interrogans serotype Hardjo infection in northern Ireland", Veterinary Research, 108, pp. 555-557, 1981.

\section{Author Profile}

Dr. D. Rani Prameela received Bachelor degree of Veterinary and Animal Sciences in 1990, Masters in Veterinary Microbiologyin 1992 and Doctoral degree programme in 2010 at College of Veterinary Sciences, Sri Venkateswara Veterinary University, TIrupati and worked as Assistant Professor from 2001 to 2012 and Associate Professor from 2012 to till date. Presently working as Head at State Level Animal Disease Diagnostic Laboratory, Sri Venkateswara Veterinary University, Tirupati, Andhra Pradesh, Ind 